\title{
King Amade Tsiyon (r.1314-1344) Military Expedition to South West Ethiopia: In the Case of Kingdom of Hadiya
}

\author{
Anwar Ayano Idris \\ Raya University, College of Social Science and Humanities \\ Department of History and Heritage Management
}

\begin{abstract}
The aim of this study is to reconstruct a history early history of the Hadiya Kingdom. With the rise of the Solomonic Dynasty in 1270, an epoch of military, political, and cultural expedition of the Christian kingdom to the south was usually mentioned. The political geography, early campaign of the Christian kingdom against Kingdom of Hadiya, its impacts on the kingdom of Hadiya and their reaction, and their alliance between other Muslim states were the focal points of this study. Hadiya was one of the seven Muslim states in Ethiopia and it was one of the strongest among them. However, due to several conflicts against Christian kingdom in the early thirteenth to seventeenth centuries they seem to have reduced their political power and territories as well as the numbers population became reduced. Therefore, to carefully understand their exact geographical location of them may be difficult. Instead of a fairly scattering of geographical situations with population densities varying according to their advantages of peace as well as natural resources great agglomeration of population had emerged, often centered on relatively difficult terrain and separated one another by considerable tracts of geographical setting. The methodology employed was qualitative one. The study was conducted based on reliable primary and secondary sources.
\end{abstract}

Keywords: Kingdom of Hadiya, King Amano, King Amde Seyon and territorial Expansions

DOI: $10.7176 / \mathrm{HRL} / 52-01$

Publication date: December $31^{\text {st }} 2020$

\section{Introduction}

With the rise of the Solomonic Dynasty in 1270, an epoch of military, political, and cultural expedition of the Christian kingdom to the south was usually mentioned. This was mainly described in the chronicles of Christian kingdoms and the works of the Arabian historiographers. ${ }^{1}$

The famous chronicle Kebra Negast (glory of kings), written in the thirteenth century, was presumably the earliest literary document, as far as we know in which the name "Hadiya" were mentioned. ${ }^{2}$ A number of Muslim principalities existed on the Somali coast and eastern escarpment of the Ethiopia highland. Hadiya was the westernmost of seven political units connected in confederation of which was named after its capital Zaila on the northern Somali coast the other were Ifat, Dawaro, Arbabni, Sharkha Bale, and Dara; they were existed between the thirteenth to sixteenth centuries. Hadiya seems to have occupied a large territory between the western Harar plateau and the eastern escarpment of the Refit valley which is now mainly inhabited by ArsiOromo. ${ }^{3}$ Within it, we are told that the Ethiopia emperor defeated the Hadiya, hereditary enemies of the Christian state, and devastated their land. ${ }^{4}$ In 1286/87 the name "Hadiya" was also referred to without any further comment, in the connection with the Shawa. ${ }^{5}$

Hadiya was then apparently well known to the Ethiopia body politic this was suggested by Ethiopia's medieval epic the Kebra Nagast (Glory of Kings) which, though written at Aksum, in the far north of the empire makes reference to the province. The passage clam that Menelik I, son of the queen of Sheba, on one occasion made war on the Hadiya people. Though not to be taken historically the passage provides interesting evidence of a northern Ethiopia awareness of the Hadiya identity. ${ }^{6}$

\section{Political Geography of Hadiya Kingdom}

The political-geographical location as it after the upheavals of the Oromo expansion induced scholars attempting to reconstruct the historical map, to locate the territory of the old state of Hadiya in the regions on both sides of

\footnotetext{
${ }^{1}$ Ulrich Braukamper, "The Colorations of Oral Tradition and Historical Records in the Southern Ethiopia: A Case Study Hadiya/Sidama Past." Journal of Ethiopian Studies, Vol. XI.No.2. Pp.29-50 p.29 Addis Ababa, 1972

2. The Queen Sheba and Her Only Son Menelik I Kebra Nagast (Glory of kings), translated by E.A. Wallis Budge (Cambridge: Ontario, 2000), p.141

${ }^{3}$ J. Spencer. Islam in Ethiopia. (London: Oxford University Press, 1955), p.47

${ }^{4}$ Kebra Nagast (Glory of kings), p.141

${ }^{5}$ Taddesse Tamrat, The Abbots of Dabra-Hayq 1248-1535, Pp.132-137 (quoting original manuscript No. 81 from the British museum, London)

${ }^{6}$ Kebra Nagast (Glory of kings), p.141
} 
the upper Gibe. ${ }^{1}$ Bieber even likened Addio, the western part of Keffa with Hadiya. An important argument for the localization in the upper area was presented by the fact the Hadiya still exists there as an ethnic denomination for a considerable part of the present inhabitants. ${ }^{2}$

All contemporary Hadiya more or less brightly relate to a tradition, which is undoubtedly impressed by Muslim value concepts, of an original homeland in the east and of Arabic ancestors. It has already been stressed that these versions stereotypically repeated among many Cushitic peoples, who have been intensively confronted with culture, are of very limited reliability.

Braukamper refer to Ibn-Said, Hadiya was situated south of Yifat, which by that time (in the thirteenth century) reached eastward as far as the Somali coast. ${ }^{3}$ Abu'l Fida probably fixed Hadiya geographical position as $7^{\circ} \mathrm{N}$ latitude and $57^{\circ} 3^{\prime}$ East longitude in an area between the equator and the first. ${ }^{4}$ Whereas al-Umari and his advocator Maqiriz possessed only vague idea of its extent: the length was nine day and breadth eight days. ${ }^{5}$ Analysis of the Arabic geographers, especially their information that Hadiya was part of the Zaila confederation, includes some later scholars to associate it with Adal. Paulitschke did not completely accept the hypothesis of their original identity, but the study of information sources led him to the conclusion that Hadiya in an early phase had once been situated in the east of the Somali peninsula. ${ }^{6}$

The confusion between Hadiya with that of Hawiya, an important the Somali clans, has already been indicated by various authors. ${ }^{7}$ Alvarez's report that in the sixteenth century Hadiya extended to Mogadishu can only mean that it reached so far the southeast that it went beyond the geographical horizons of the informants. A direct connection with the Somali coast can nevertheless be excluded as this might be confused with Hawiya. ${ }^{8}$

The inconsistencies of location largely resolve themselves if we take into account a more dynamic process of ethnic and geographical displacements. It can, indeed, be concluded from the written records that in the case of Hadiya territorial shift might have taken place from the east, Harage, to the highlands west of the Rift Valley. This is confirmed by the people about their migrations. At an early period of the Hadiya before they expanded towards the interior of Ethiopia, they were all concentrated within a limited area on the east part of the Horn Africa, and in later times when a political and territorial differentiation had occurred, they were identified with an appletion of the confederation of Zayla. ${ }^{9}$

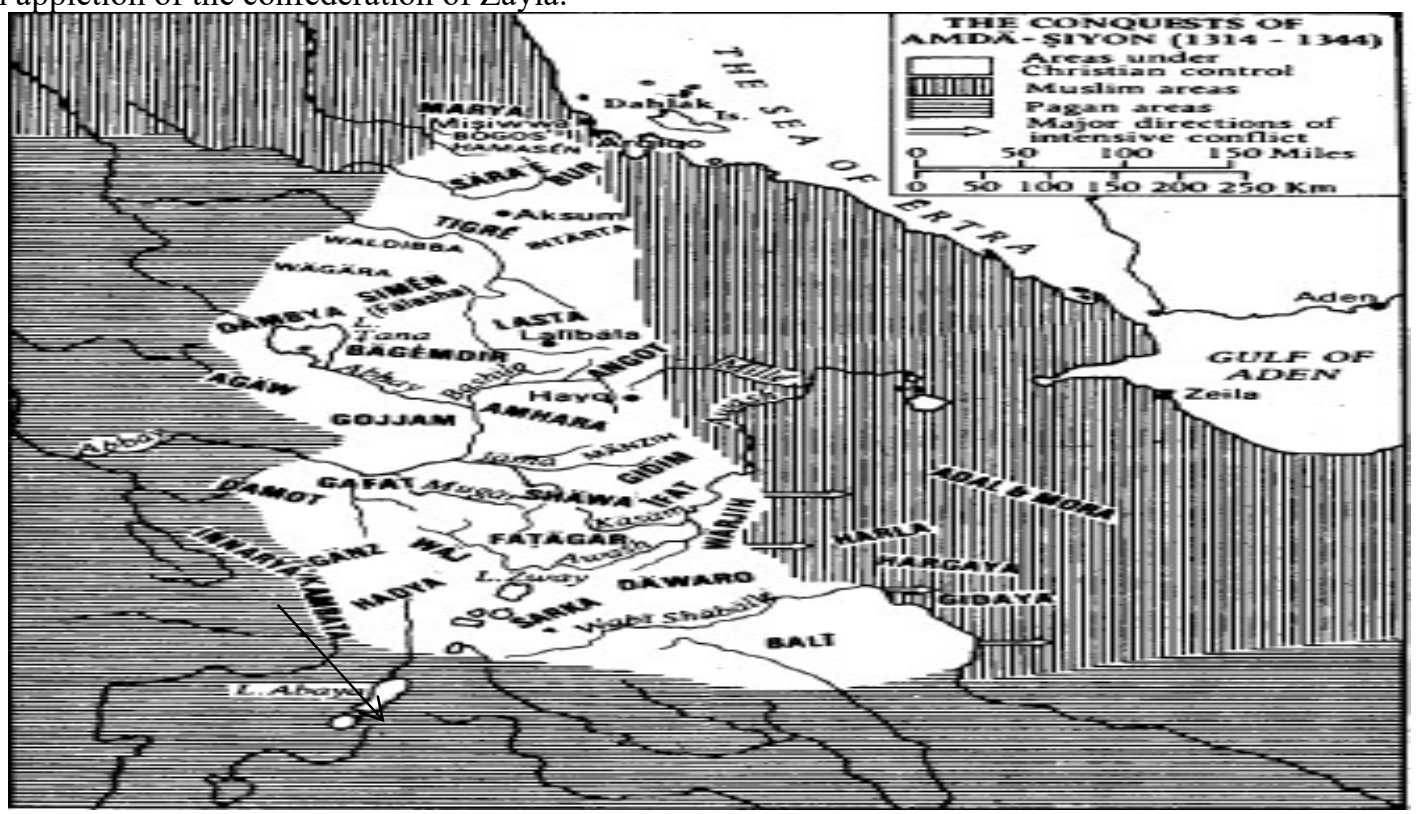

1.1 map the kingdom Hadiya in $13^{\text {th }}$ century ${ }^{10}$

${ }^{1}$ Charles Fraser Beckingham, and Gorge Wynn Briton, Huntingford, (ed., Trans.) Some records of Ethiopia 1593-1646; Being Extracted from the History of High Ethiopia or Abyssinia by Manoel De Almeida, together with Bahrey's History of the Galla, London: Hakluyt Society, 1954. p.453

${ }^{2}$ Islamic History and Culture in Southern Ethiopia: collected essays”.( Munster Lit Verlage Munster, 2004),p. 60

${ }^{3}$ Ibid, p.61

${ }^{4}$ Maurice Gaudefroy-Demombynes, trans. Maslik el-Absari fi Mamalik, l'Afrique, moins l'Egypte (par Fadl Allah al-Umari [al-Umari]( Paris, 1927)p.9

${ }^{5} \mathrm{Ibd}, \mathrm{p} .13$

${ }^{6}$ Paulitschke, p. 44

${ }^{7}$ Urlich braukamper, Islamic history and culture in southern Ethiopia, p.61

${ }^{8}$ Charles Fraser Beckingham, and George Wynn Brereton Huntingford, (eds.), The Prester John of Indies. A true relation of the Land of the Prester, Francisco Alvarez, Cambridge, 1961. p.318

${ }^{9}$ Ulrich Braukamper, Islamic history and culture in southern Ethiopia, p.61

${ }^{10}$ Taddesse Tamrat, Church and State in Ethiopia 1270-1522. London, Oxford Caldron, 1972.1972, p.133 


\section{The First campaign of King Amdä Sevon 1316/17 to the Kingdom Hadiya}

With the rise of the Solomonic Dynasty in 1270, an epoch of military, political, and cultural expedition of the Christian kingdom to the south was usually mentioned. This was mainly described in the chronicles of Christian kingdoms and the works of the Arabian historiographers. ${ }^{1}$ It was reported that King Amdä Şeyon inherited the military and political problems of the turbulent reign of his immediate predecessors. These among others included the final consolidation of the powers of the new dynasty in all the Christian provinces; the causes had been in the Agaw districts in the north-west, the kingdom of Gojjam; in the west and that of Damot in southwest and the more important struggle with the Muslim Sultanates in the east and southeast. ${ }^{2}$

A state of uneasy peace with the Muslim seems to have existed at the time of Amdä Seyon's accession to the power. One of the most important reasons for Christian-Muslim conflicts was the need for the Kingdom to ensure a free and unmolested passage of its nationals or agents to the Red sea and beyond. The Muslims had always enjoyed an almost complete monopoly of long distance trade in the whole region. Sometimes they acted as agents of the Christian Kings, sometimes as independent traders. In either case Muslim ruler were masters of the areas through which the main trade routes passed. This technical dependence of the Christians on the service and goodwill of the Muslims was easily liable to be used for political purposes, especially in the in the time of hostile relations. This appears to encounter between Amdä Şeyon and the ruler of Ifat. ${ }^{3}$

The Reign of King Amdä Seyon had been considered as the most important era for the expansion of the Christian Kingdom. Taddasse Tamrat quotes Amda Şeyon's chronicle, which tells us much about his campaigns, particularly the one of 1332, then, have been practically few data about the early years of his reign. However, as Taddesse mentions there is various information at all about how and when Damo, Gojjam and Hadiya were first effectively conquered and annexed. ${ }^{4}$

The kingdom of Hadiya was one territory of medieval Kingdoms of Ethiopia, which was situated in the highland to the south west of Christian kingdoms and further west as far as Šärkä. One of the earliest campaigns of King Amdä Şeyon was conducted against Damot and Hadiya. It took place in the year 1316/17 and the king was commemorated his success. ${ }^{5}$ The territory probably became an integral tax paying part of the Christian kingdom early in the further conflicting situation during the reign of Amdä Şeyon. ${ }^{6}$ Taddesse by referring to a manuscript which was written in the monastery of Debre Hayq states that, after the conquered of Damot around 1316/17 he preceded to Hadiya;

".... God gave me all the people of Hadiya, men and women without number, whom I exiled into

another area". Having thus gained control over this territory, he had recruited many of its inhabitants to serve in his army. ${ }^{7}$

King Amdä Şeyon seems to have made at least one land grant to a courtier from Hadiya. It states that the man, surprised at the expense the king incurred in purchasing mules, proposed that, they have been bred in the royal stable. The king was so pleased that he had allowed him to choose whatever gult or estates he desired. ${ }^{8}$

These early victories had given the king a great source of wealth and manpower in the rich interior south and south west of the river Awash. At first, the king's control of these areas seems to have been minimal and limited to collecting occasional tributes from the local rulers. This appears to have been the case with Hadiya in particular. ${ }^{9}$ Al-Umari mentions Hadiya as one of the seven Muslim states in the Ethiopia region, placing it west of Bali. It is not clear from his work when exactly Muslim influence become predominant in Hadiya ${ }^{10}$ The Christian report of Amdä Şeyon's successful campaign in Hadiya about 1316/17 does not at all imply that the king was fighting against Muslim or traditional religion followers troops. ${ }^{11}$

Al-Umari's Muslim state of Hadiya may have been in fact traditional religion believers in the kingdom in which a growing number of Muslim merchants had been settled, they had probably also converted some of that in Amdä Şeyon's time the ruler of a country were as yet Muslim. ${ }^{12}$ It's quite clear, however, that the influence Muslims in the area were very strong and they used it to undermine the consolidation of Christian power there.

\section{The Second Campaign of King Amdä Şeyon to Hadiya 1332}

Just before 1332, Amdä Şeyon led another expedition against the kingdom of Hadiya to offset such hostile

\footnotetext{
${ }^{1}$ Ulrich Braukamper, 1972, p.2

${ }^{2}$ Taddesse Tamrat, 1972, p.134

${ }^{3}$ Taddesse Tamrat, 1972 p. 132

${ }^{4}$ Taddesse Tamrat, 1970, p.95

${ }^{5}$ Ibid

${ }^{6}$ Ibid

${ }^{7}$ Ibid. p.96.

${ }^{8}$ Richard Pankhurst, p. 77

${ }^{9}$ Ibid.

${ }^{10}$ Fadl Allah al-Umari, p.9.

${ }^{11}$ Taddesse Tamrat, 1970, p.96.

${ }^{12}$ Fadl Allah al-Umari, p.10
} 
activities. $^{1}$ Hadiya's incorporation into the Christian Kingdom was not without difficulties. As Richard Pankhurst cited Amdä Şeyon's Chronicle reports that, Sultan Sabr al-Din's rebellion spread from Ifat to Hadiya. The local governor who was referred to as Amano ${ }^{2}$ was advised by Bal'am, "prophet of darkness" to rebel.

"Go not to the king of Amdä Şeyon, (i.e.) to the emperor, he was said to have declared. Do not give him gifts: if he comes against you, be not afraid of him, for he will be delivered into your hands and you will cause him to die with his army". ${ }^{3}$

The Hadiya ruler who we may assume from his name, was almost certainly a local man hearkened, it is said, to the counsel of this lying prophet and rebelled the emperor then rose up in anger and set out for Hadiya, where he slew the inhabitants of the country with the point of the sword. Describing the revenge shaped by the warlike emperor on the people of Hadiya the chronicler declared. Some he destroyed and those who survived, he took into captivity together with their old ones and young ones men, women and children, he led them away to the capital of his kingdom the false prophet Bala'm then took himself off and fled to the land of Ifat. ${ }^{4}$

But Donald N. Levine described term Amano as a person's name, not a title. He got the term Amano presented this idea as is used in the song of a century after Zar'a Ya'eqob. ${ }^{5}$ Braukamper point out that, the term Amano was the title of of Hadiya kings. As a result, he counted the genealogy of Hadiya but he doesn't get the name "Amano" from their ancestor. But it seems that the term Amano apart a variety of ages, frequently described as his name alone is not enough information to be able to argue that title. ${ }^{6}$ Amano According to legend, this time of conventional names of people believed to name represents. The occurrence of repeating the name apart thus was becoming the only name that has to be attractive and well-meaning people.

Amano was considered as the leader of Hadiya during the first war between Hadiya Kingdom and King Amdä Şeyon. After his defeat, Amano in accordance with the custom of the time taken captivity describes the Christian kingdom.

Despite such punishment many men from Hadiya served in Amdä Şeyon's army, which also contained soldier from neighboring Damot, as well as from the central province of Šawä. As Pankhurst cited his chronicle which tells of him dispatching a Hadiya contingent together with soldiers from Damot, on an expedition in 1332 against the people of Semen, Wogara, and Şalamt. ${ }^{7}$ Already in 1332 a contingent called Hadiya was sent as part of the Christian troops to suppress a Falasha revolt in Wagara.

According to Amdä Şeyon's chronicle, the ruler of Hadiya, called Amano, who refused to come to the king Amdä Şeyon court and submits the usual tributes. He was encouraged in this by a Muslim false prophet. Amdä Şeyon response to this was very swift. He led his army into Hadiya, pillaged the country, and took many prisoners including Amano. The Muslim preacher himself felt to Ifat. Amdä Şeyon seems to have made a thorough job of his re-conquest of Hadiya which soon became an important source of manpower for the Christian army, of which contingents from Hdiya would henceforth from a considerable part of Ethiopia. ${ }^{8}$

With Hadiya and the regions immediately to the north and west under his control, Amdä Şeyon was now within measurable distance of achieving his initial program of controlling the inland trade of the Muslims. The re-conquest of Hadiya in particular dealt a hard blow to the slave trade for which it had long been the major source of supply. It was largely on this trade that Muslim activities in the area were based, and the effect was felt, not only by the local trades of Hadiya and their immediate neighbors, but by all chain of Muslim settlement as far as the red sea coast.

Moreover, Christian power and influence was fast growing in the newly conquered regions, and it looked as it would soon extend further afield. The future of Islam purse was threatened as it had never been threatened before. $^{9}$

The response of the Muslim to this new challenge was equally striking. Until now the different the settlement had been operating largely independently of one other, and the attempt of Ifat to create united Muslim front had been only partially successful in its immediate neighborhood, and even that had already been seriously damaged by the early successes of Amdä Şeyon against Haqadin and Dardir. Now, however, the time was ripe for a united action against the Christian intruder. Amdä Şeyon's dauntless campaign in the areas hitherto unknown to Christian troops further shook their sense of security, and made the need for a league even stronger. ${ }^{10}$

Once again, Iafat took the lead in ensuing hostilities. Sabradin was Ruler of Ifat at a time, and he seems to

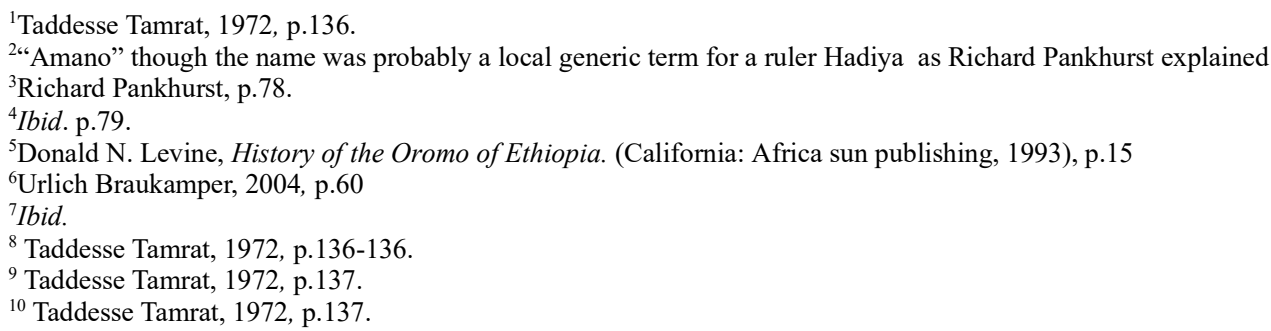


have been at the center of a new movement for which he was perfectly suited as the son of great Umar Walasma. Although evidence is lacking to determine the intellectual or doctrinal content of this movement there are references in the chronicle to religious leader helping in its organization. One of this the false prophet of the Christian conquest chronicler, who fled to Ifat on the Amdä Şeyon conquest Hadiya. He appears to have continued his hostile propaganda in Ifat also, where he is represented as one of the advisor Sabradin who was the ruler of Ifat. ${ }^{1}$

The account of Ibn Fada Allah al Umari and Meqriz valuable hints of Hadiya towards the close of Amdä Şeyon's reign is embodied in al Umari's report. It suggests that the province through small, measuring only eight days Journey by nine, ${ }^{2}$ whereas Richard Pankhurst estimated that, it may be $160 \mathrm{~km}$ 's by $180 .{ }^{3}$ Well favored by nature, it produces cereals and fruit, raised horses and animals of burden and like Däwärö and Šarkha. They used pieces of iron as primitive money. Hadiya was much involved in the slave trade, for its imported slaves from the "country of the infidels presumably nearby Christian or pagan lands. ${ }^{4}$

The castrations of slaves Al-Umari learned from merchants who had visited the territory had been forbidden by the Christian King (perhaps in fact Amdä Şeyon). The operation was however often carried out illegally at the nearby town Wašlu ${ }^{5}$ whether the trader took their slaves for castration, which greatly increased their value. Eunuchs were then convoyed to Hadiya where they remained until they recovered. The province's inhabitants were reputedly skilled in curing the victims of such operations, but the number of slaves who died were said to have been greater than those who survived. ${ }^{6}$

The Kingdom of Hadiya was a relatively small but powerful state. Conceivably densely populated, it could, raise a large army of no less than 40,000 cavalry; and, at least twice as many foot soldiers. The province thought out this timer remained firmly under imperial suzerainty. A provincial ruler whom Maqrizi referred to by the old name or title of Amano fought on the Christian side against sultan Sad-ad Din of Ifat, but was defeated. The Amano was put to flight and a large of his men captured. ${ }^{7}$

Taddesse suggests that, the successful campaign of Amdä Şeyon in Hadiya 1316/17 does not imply at all that the king was fighting against Muslim troops. According to Taddesse based on Al- Umari, Hadiya may have been in fact a pagan kingdom in which a growing number of Muslim merchants had been settling, they had probably also converted some of the local people. But it doesn't seem that in Amdä Şeyon time the ruler of country were as yet Muslim. ${ }^{8}$ It is quite clear, however, that the influence of the Muslim in the area was very strong and they used it to undermine the consolidation of Christian power there. Just before 1332, Amdä Şeyon led another expedition against the kingdom of Hadiya to offset such hostile activities. ${ }^{9}$

King Amdä Şeyon succeeded Widim Ra'ad after the death of Täkle Haymanot. His predecessor's kingdom had already included the central Šawan plateau, where the religious activities of the saint had been conducted and it was from this area that the new king led his successful campaign against the Muslims to the east and southeast. Already before the campaign of the 1332, he had also reduced Damot and Hadiya to under his controls. ${ }^{10}$ These military did not, however, mean an immediate Christianization of inhabitants. But they tremendously boosted Christian moral and contacts between the Christian communities and new subject area become open and more frequent. The numerous captives of the war reduced into slavery, some were distributed among the conquering troops, and another was probably sold to the Christian settlers in the north. The contingents', frequently rose from the conquered area, always took part in the campaign of the king, side by side with Christian troops. As such, they were increasingly exposed to Christian influence in the religious sense also. All these offered invaluable opportunities for the expansion of Christianity. ${ }^{11}$

Donald N. Levine described that term Amano was a person's name, not a title. He got the term Amano presented this idea as is used in the song of a century after Zar'a Ya'eqob. ${ }^{12}$ Braukamper point out that, the term Amano was the title of of Hadiya kings. As a result, he counted the genealogy of Hadiya but he doesn't get the name "Amano" from their ancestor. But it seems that the term Amano apart a variety of ages, frequently

\footnotetext{
${ }^{1}$ Taddesse Tamrat, 1972, p.137

${ }^{2}$ Fadl Allah al-Umari, p. 10 .

${ }^{3}$ Richard Pankhurst, Pankhurst, Richard. The Ethiopia Border Lands Essays. In Regional History from Ancient Time to the End of the 18 ${ }^{\text {th }}$ Century. (Lawrenceville, N.J., Asmara. 1997) p.79.

${ }^{5}$ As Ibin Said point out that, there was a place called Wašlu which was found north of Hadiya. But for the first time Wašlu was used by al Umari. Arab Faqi (Futuh Al Habasha) mentioned the place as Wašuloh it is probably the former slave markets and castration takes place during the time of King Amdä Səyon. Also Wašuloh was the place where slave exported to Middle East and other countries.

${ }^{6}$ Al- Umari, p. 11

${ }^{7}$ G.W.B Huntingford, 1952, p.27

${ }^{8}$ Taddesse Tamrat, 1972, p.136

${ }^{9}$ Kibamo Addise, Kibamo Addise. “A Political History of Hadiya 1890-1941. M.A Thesis (Addis Ababa University 2007) p.17

${ }^{10}$ Taddesse Tamrat, 1972, p.155.

${ }^{11}$ Ibid, p. 156

${ }^{12}$ Donald N. Levine, History of the Oromo of Ethiopia. (California: Africa sun publishing, 1993), p.15
} 
described as his name alone is not enough information to be able to argue that title. ${ }^{1}$ Amano According to legend, this time of conventional names of people believed to name represents. The occurrence of repeating the name apart thus becomes the only name that has to be attractive and well-meaning people.

Amano was considered as the leader of Hadiya during the first war between Hadiya Kingdom and King Amdä Şeyon. After his defeat, Amano in accordance with the custom of the time taken captivity describes the Christian kingdom.

Finally, the defeat of Hadiya was alarmed such as a container (hostage) of Hadiya people encourages good behavior and relatives. This action was extended on a day that was defeated leaders. ${ }^{2}$

\section{References}

Abebe Gichamo, "The Relation between Islam and Christian in Hadiya: Historical Analysis the Rise, Expansion and Current Status of Islam and Christianity among Hadiya People, Southern Ethiopia". (B.A) senior essay. Addis Ababa, Mekane Iyasus Theology Collage, 2005.

Alemu Haile, (Trans.) Ethiopia History: The Chronicles of King Zarä Ya'əqob And Ba'ada Maryam, Addis Ababa Sirak Printing Press, 2007.

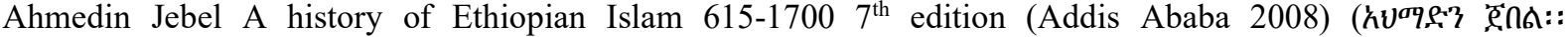

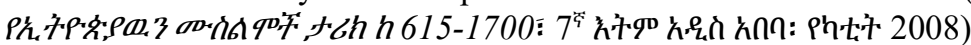

Alebachew Kemiso and Samuel Handamo People of Hadiya History and culture Sefri printing PLC. 2002.

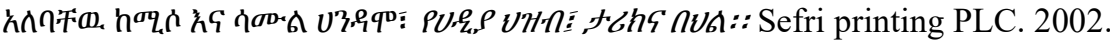

Alemu Haile, (trans/edit) Chronicle of asé Säşä Dengel, (Addis Ababa, June 1997).

Asrat Ermolo. "A Political history of Hadiya from 1941-1991”. M.A Thesis. Addis Ababa University, 2013.

Beckingham, Charles Fraser and Huntingford, Gorge Wynn Briton, (ed., trans.) Some records of Ethiopia 15931646; Being Extracted from the History of High Ethiopia or Abyssinia by Manoel De Almeida, together with Bahrey's History of the Galla, London: Hakluyt Society, 1954.

Beckingham, Charles Fraser - George Wynn Brereton Huntingford, (eds.), The Prester John of Indies. A true relation of the Land of the Prester, Francisco Alvarez, Cambridge, 1961.

Braukämper, Ulrich. "The Colorations of Oral Tradition and Historical Records in The Southern Ethiopia: A Case Study Hadiya/Sidama Past." Journal of Ethiopian Studies, Vol. XI.No.2. Pp.29-50 Addis Ababa, 1972 Geschichte Der Hadiyya Süd-Äthiopiens. Von Den Anfängen Bis Zur Revolution 1974. Franz Steiner Verlag, Stuttgart 1980.

"Aspects of Religious Syncretism in Southern Ethiopia". Journal of Religion in Africa. Vol. XXII. No.3. 1992, pp. 194-207.

"Islamic History and Culture in Southern Ethiopia: collected essays". Munster LIT VERLAGE Munster, 2004.

and Tilahun Mishago, Praise and Teasing: Narrative Songs of the Hadiya in Southern Ethiopia. Germany: Frobenius Institute Frankfurt an-Maim. 1999 "Fandano" Encyclopedia Æthiopica, Vol.2, 2005.

Cerulli, Enrico. Islam Past and Present (Tran., ed.) Emran M. Waber, Rome, 1971.

Chernetsov, S. B. Who Wrote the History of King Sarşa Dəngəl? Was it the Monk Bahrey? Proceedings of the $8^{\text {th }}$ international conference of Ethiopian Studies. Vol. 1. 1984, pp. 131-146.

Medieval Ethiopian Historiography and their methods. Proceedings of $9^{\text {th }}$ International conference of Ethiopian Studies. 1986, PP. 191-200.

Cothari, C.R. Research Methodology, Methods and Techniques. New Delhi: New age International Publishers, 2004.

Davis, J. Alan. "The Sixteenth Century Jihad in Ethiopia and the Impact on Its Culture Implicit Factors behind the Movement". Journal of the Historical Society of Nigeria. Vol. II 567-592 1963.

Deresse Ayenachew. "Evolution and Organization of the Čäwa (њP) military regiments in Medieval Ethiopia". Annales D'Ethiopie, 2012.

Gaudefroy-Demombynes, Maurice. Maslik el-Absari fi Mamalik, l'Afrique, moins l'Egypte (par Fadl Allah alUmari. Transl. Par M. Gaudefroy-Demombynes). Paris, [al-Umari]. 1927.

Gedeon Addise. "A Socio-Economic and Cultural History of Hadiya from 1941-1991”. M.A. Thesis Addis Ababa University, 2008.

Haberland, Eike. The influence of Christian Ethiopian Empire on the southern Ethiopia.Second international conference of Ethiopian studies, Manchester, 1964.

Haile Bubamo Arficho. "Some notes on traditional Hadiya Women.” Journal of Ethiopian Studies, 11 (2): pp. 131-154.

${ }^{1}$ Urlich Braukamper, Islamic History and Culture in Southern Ethiopia 2004, p.60

${ }^{2}$ Ibid. 
. "The Linguistic influence of Hadiya on Northern Ethiopia". Addis Ababa, 1972

"Some Notes on the Fandano Religion of Hadiya (South Western Shawa)".paper

Presented to the first annual conferences of the Historical society of Ethiopia, Addis Ababa, 1971.

Hiruy Wolde Silassie, Blatten Geta. The history of Ethiopia: From the Queen Sheba the Great Victory of Adwa. Addis Abeba: Central Press, 1927

Huntingford, G.W.B. The Historical Geography of Ethiopia. United States: Oxford University Press, 1989. "Arabic Inscription in Southern Ethiopia". In: Antiquity XXIX: 230-33

Jeylan Wolyie Hussein, "A Critical Review of the Political and Stereotypical Portrayals of the Oromo in the Ethiopian Historiography”, Nordic Journal of African Studies, Vol.15, No.3. 2006

Kibamo Addise. "A Political History of Hadiya 1890-1941. M.A Thesis. Addis Ababa University 2007.

Levine, Donald. Greater Ethiopia: The evolution of multi-ethnic society. Chicago: The University of Chicago Press, 1974. History of Oromo of Ethiopia. California: African Sun Publishing, 1993.

Maqrizi, The History of Muslim Kingdoms in Abyssinia From Latin Version E.T Rikok 1700 By G.W.B Huntingford Type Script 1952.

Martin, E.G. "Mahdism and Holy Wars in Ethiopia before 1600". Proceedings of the Seminar for Arabian Studies, Vol. 4, and Proceedings of the Seventh Seminar for Arabian Studies held at The Middle East Centre, Cambridge: Archaeo-press Publishing Ltd, on 28th and 29 June, 1973, pp. 106-117.

Mohammed Hassen. "The Pre Sixteen Century Oromo Presence inside the Medieval Christian

Kingdom of Ethiopia". African series of Maxwell school of citizenship and Public affairs. No. 44. 1991, pp. 4361.

. The Oromo of Ethiopia: a History (1570-1860), Cambridge: Cambridge University Press, 1994.

"Futuh Al-Habaša: The Conquest of Abyssinia [16 ${ }^{\text {th }}$ Century] by Šihab ad Din Ahmed bin Abd alQader bin Salem bin Utman; Paul Lester Stenhouse; Richard Pankhurst. International Journal of Ethiopian Studies. Vol. 1.No. 2. 2004.

Pankhurst, Richard. The Ethiopia Border Lands Essays. In Regional History from Ancient Time to the End of the $18^{\text {th }}$ Century. Lawrenceville, N.J., Asmara. 1997

Perruchon, J. Histoire d'Eskender, Amdä Şeyon Et Na’od, In Journal Asiatique, 1894.

. "Notes pour l'ehistoire D'Ethiopie, règne de Sartsa-Dengel ou Malak-Sagad Ier (1563-5197)". Revue Sémitique. Vol.4. 1896.

Philipson, David. Ancient Ethiopia, Aksum: Its Antecedents and Successors. London: British Museum press, 1998.

Rossini, Conti. "La Stroria di Lebna Dengel, D’Etiopia no alle prime lotto contro Ahmed ben Ibrahim". In: Rendiconti della reale academia de Lincei 1894.

Šihab Ad Din Ahmed Bin Abd Al-Qadir Ben Salem Bin Utman (Arab Faqih), Futuh Al- Habasha (Conquest of Abyssinia) [16 ${ }^{\text {th }}$ century], translated by Paul Lester Stenhouse

With Annotation by Richard Pankhurst Tsehai Publisher and Disturber, 2003.

Taddesse Tamrat, the Abbots of Dabra-Hayq 1248-1535. Journal of Ethiopian Studies, Vol. 8, No.1 Institute of Ethiopian Studies, January 1970.

Church and State in Ethiopia 1270-1522. London, Oxford Caldron, 1972.

The Glorious Victories of Amda Şeyon King of Ethiopia (Trans/Edit) By B.W.G. Huntingfrod, Oxford Clarrendon Press 1965.

Tilahun Mishago, An over view of Hadiya History from the $12^{\text {th }}$ to $18^{\text {th }}$ centuries. Addis Ababa, May 2014.

Trimingham, J. Spencer. Islam in Ethiopia. London: Oxford University Press, 1955.

Vansina, Jan. Oral Tradition as History. Madison: The University of Wisconsin Press, 1985.

The Use of Ethnographic Data as source for History. In: T.O Rangerd (Ed.): Emerging themes of Africa History; pp. 97-124. London. 